\title{
Pendidikan Etika Bergaul Islami Dalam Keluarga "Nilai Pendidikan Etika Berlaku Adil Orangtua dengan Anak dalam Pergaulan Keluarga Perspektif Hadits"
}

\author{
Syahraini Tambak \\ Universitas Islam Riau, Indonesia \\ Jl. Kaharuddin Nasution No. 113, Perhentian Marpoyan, Kota Pekanbaru, Indonesia. \\ Email: syahraini_tambak@fis.uir.ac.id
}

\begin{abstract}
This paper aims to explore the values of ethical education that are fair to parents and children in family relationships based on the hadith of the Prophet Muhammad, sourced from Nu'man bin Basyir. The hadith about "is valid for your children," which was narrated by Abu Dawud as a authentic quality hadith based on the research of Shaykh Muhammad Nashiruddin al-Baniy. There are four educational values contained in this hadith, namely; Equality education, where applying a fair attitude toward parents in socializing in the family makes children feel valued and get attention. Affection education, where parents are impartial, and do not discriminate between children, encouraging the emergence of affection. Democratic education, with the relationship of parents to children in an atmosphere of justice will develop respect. Harmony education, with fair behavior of parents in interactions with their children contributes to the creation of harmony between children. This paper is useful in constructing an ethics education to get along with the principle of justice in the family. Parents are expected to be able to apply this hadith as a guide in building a family.
\end{abstract}

Keywords: Social Ethics, be Fair, Family, Parents

\begin{abstract}
Abstrak: Tulisan ini bertujuan mengeksplore nilai-nilai pendidikan etika berlaku adil orangtua dengan anak dalam pergaulan keluarga berdasarkan hadits Nabi Muhammad SAW, bersumber dari Nu'man bin Basyir. Hadits tentang "berlaku adillah terhadap anak-anakmu," yang diriwayatkan oleh Abu Dawud dinilai sebagai hadits yang berkualitas shahih berdsasarkan penelitian Syaikh Muhammad Nashiruddin al-Baniy. Terdapat empat nilai-nilai pendidikan yang terkandung dalam hadits ini yaitu; Pendidikan kesetaraan, di mana menerapkan sikap berlaku adil orangtua dalam bersosialisasi di keluarga membuat anak merasa dihargai dan mendapat perhatian. Pendidikan kasih sayang, di mana orangtua tidak memihak, dan tidak membeda-bedakan diantara anak, mendorong munculnya kasih sayang. Pendidikan demokrasi, dengan hubungan orangtua pada anak dalam suasana keadilan akan berkembang sikap menghargai. Pendidikan kerukunan, dengan perilaku adil orangtua dalam interaksi dengan anak-anaknya berkontribusi bagi terciptanya kerukunan antara anak. Tulisan ini bermanfaat mengkonstruksi pendidikan etika bergaul dengan prinsip keadilan dalam keluarga. Bagi para orangtua diharapkan dapat menerapkan hadits ini sebagai pedoman dalam membangun keluarga.
\end{abstract}

Kata Kunci: Etika Bergaul, Berlaku Adil, Keluarga, Orangtua

Jurnal Pendidikan Agama Islam Al-Thariqah Vol. 4, No. 1, Januari - Juni 2019

Received: 26 March 2019; Accepted 06 April 2019; Published 16 May 2019

*Corresponding Author: syahraini_tambak@fis.uir.ac.id 


\section{PENDAHULUAN}

Keluarga merupakan institusi pertama yang menjadi lingkungan hidup individu (Hatmanto, 1986; Sulaiman, 1994). Semenjak lahir sampai mampu berdiri sendiri, seseorang dibesarkan di lingkungan keluarga. Semua kebutuhannya, baik fisik maupun mental, selama pertumbuhan dipengaruhi oleh keluarga (Tambak, 2013). Dalam kehidupan berumah tangga, orangtua memiliki peranan yang sangat penting dalam perkembangan anak-anaknya, karena anak merupakan karunia dan amanah dari Allah SWT yang harus dijaga. Hal terpenting dari salah satu sikap orangtua diterapkan kepada anakanaknya, baik dalam hal materi maupun non materi, adalah menerapkan perilaku adil diantara anak-anak dalam pergaulan sehari-hari (Hasan, 2003: 189; Tambak, 2013). Ketika orangtua mampu berlaku adil terhadap anak-anaknya, maka mereka memiliki kecenderungan untuk bersikap patuh terhadap terhadap segala arahan dan bimbingan dalam keluarga. Bahkan orangtua akan lebih mudah mengatur anak-anak karena semua merasa mendapat perhatian dan kasih sayang yang sama dalam interaksi di keluarga. Perilaku adil dalam pergaulan di lingkungan keluarga merupakan salah satu sikap mulia yang perlu diterapkan oleh setiap orangtua Muslim. Sebagai orangtua, penting untuk berprilaku adil terhadap seluruh anak-anaknya agar tidak timbul kecemburuan yang menggangu keharmonisan keluarga.

Perilaku ketidakadilan dan sikap pilih kasih orangtua dalam pergaulan dengan anak, akan menimbulkan kecurigaan pada hati anak-anak terhadap orangtua. Hal itu terjadi sebagai akibat dari ketimpangan pemberian perhatian yang cenderung pada salah satu anak sementara mengabaikan yang lain. Apalagi anak sebagai manusia ciptaan Allah SWT, kadang dihinggapi rasa iri dan dengki, menjadi pendorong munculnya pandangan berbeda diantara anak-anak jika perlakuan tidak seimbang. Hal ini dapat menjadi pemicu munculnya problematika rumah tangga antara orangtua dan anak, serta juga antara anak dengan anak (Al-Munawwar, Tambak \& Kalsum, 2003). Sedikit saja kesalahan orangtua yang terjadi dalam pergualan keluarga akan menjadi kesalahan yang besar di mata anak yang merasa dirinya tidak mendapat perhatian yang sama dengan lainnya. Dampaknya, anak menjadi sulit diatur, wibawa orangtua hilang di hadapan anak, dan pada akhirnya orangtua akan kesulitan mendidik dan menyampaikan nasehat, dikarenakan mereka telah curiga dan berburuk sangka atas perilaku orangtua.

Sebagai orangtua dituntut mengoreksi kembali sikap dirinya telah berbuat adil kepada anak-anaknya atau malah berat sebelah kepada salah satu anak dan mengabaikan yang lainnya. Bahkan orangtua dituntut untuk berhatihati agar tidak pilih kasih walaupun dia tidak menyengaja karena aka berdampak pada perilakunya terhadap anaknya. Sikap tidak adil dan pilih kasih orangtua kepada anak-anaknya memiliki dampak yang sangat buruk dan akibatnya akan dirasakan oleh orangtua itu sendiri, bahkan akan membahayakan salah satu anak mereka yang dikasihi lebih dari yang lainnya. Berkaitan dengan konteks ini, alNablisi (2002: 217), menjelaskan bahwa sikap pilih kasih orangtua terhadap anak akan menimbulkan permusuhan, kedengkian, dan kebencian antara sesama anak, yang berakibat pada terjadinya pemutusan hubungan keluarga karena sikap pilih kasih orangtua. Dampak lain yang tak kalah buruknya adalah akan muncul di masa mendatang generasi durhaka kepada orangtua dan generasi yang selalu menimbulkan permusuhan dengan saudara-saudara mereka sendiri (Athif, 2004: 246).

Begitu pentingnya etika perilaku adil orangtua terhadap anak dalam keluarga, 
karena pendidikan di lokus keluarga menjadi fondasi utama dalam pertumbuhan dan perkembangan anak. Hal ini kemudian muncul dalam salah satu hadits Nabi Muhammad SAW yang bersumber dari Nu'man bin Basyir, membicarakan pentingnya berlaku berlaku adil dari orangtua kepada anak dalam pergaulan di keluarga. Maka berdasarkan hal ini pertanyaan penelitian adalah bagaimana kualitas hadits tentang etika berlaku adil orangtua dengan anak dalam kehidupan keluarga? Apa saja nilainilai pendidikan yang terkandung dalam hadits tentang etika bergaul orangtua dengan anak berkaitan dengan berlaku adil dalam keluarga; Tulisan ini diharapkan dapat bermanfaat bagi dunia akademik bidang mata kuliah hadits tarbawi dalam mengkonstruksi pendidikan etika bergaul dengan prinsip keadilan dalam keluarga. Di samping itu berkontribusi bagi para orangtua dalam membangun keluarga dengan pendidikan etika bergaul untuk penerapan nilai-nilai keadilan pada anak dan anggota keluarga.

TAKHRIJ HADITS TENTANG ETIKA ORANGTUA BERLAKU ADIL DENGAN ANAK DALAM PERGAULAN DI KELUARGA

\section{Informasi Keberadaan Hadits}

Hadits yang membicarakan tentang etika bergaul dalam keluarga dapat dilihat pada hadits yang membicarakan tentang etika berlaku adil dalam pergaulan orangtua dengan anak. Tekait hal ini, secara pesifik dapat dikemukakan hadits tentang "berlaku adillah terhadap anakanakmu," dengan redaksi matan sebagai berikut:

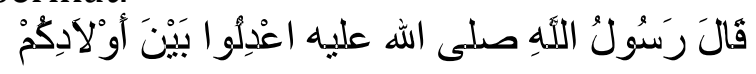

"Rasulullah SAW., bersabda, Berlaku adillah terhadap anak-anakmu." (HR. Bukhari, Muslim, Abu Dawud, al-Nasa'iy dan Ahmad).

Hadits di atas merupakan bagian terpenting dalam proses penjelasan terkait dengan etika bergaul dalam keluarga, yaitu sikap berlaku adil. Dengan menelusuri kosa kata (عدل- يعدل) اعْدِدُوا pada Mu'jam al-Mufakhrasy li al-Alfazh alHadits al-Nabawiy diketahui bahwa hadits tentang "berlaku adillah terhadap anakanakmu," terdapat dalam Sunan $A b i$ Dawud Kitab Buyu' hadits nomor 82, Shahih al-Bukhari, Kitab Hibah hadits nomor 12 dan 13, Shahih Muslim, kitab Hibah hadits nomor 12, Sunan al-Nasa'iy, Kitab Nahl hadits nomor 1, dan Musnad Imam Ahmad Jilid 4 hadits nomor 275 dan 278 (Wensinck, 2008: 236).

\section{Sanad dan Matan Hadits}

Hadits dimaksud dalam riwayat $\mathrm{Abu}$ Dawud (2003: 315) di atas, sanad dan matan hadits pada jalur tersebut selengkapnya dapat dilihat pada ungkapan hadits yang akan dikemukakan, yaitu:

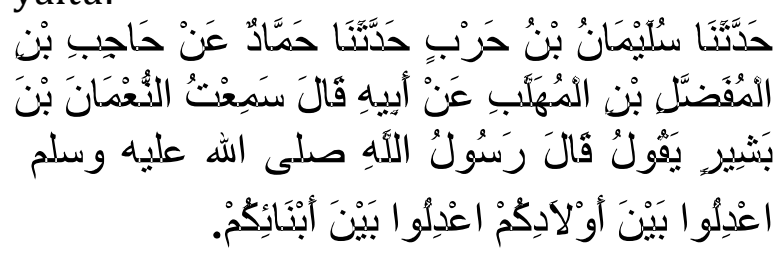

Adapun rangkaian nama-nama para periwayat hadits yang terdapat pada jalur periwayatan Abu Dawud dapat dilihat pada skema yang dikemukakan sebagai berikut:

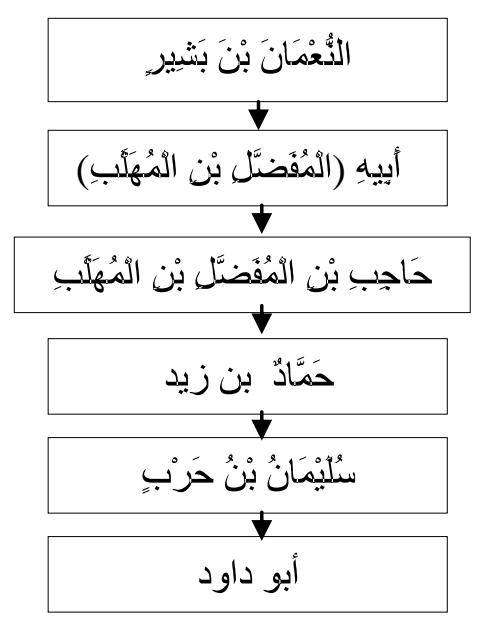

Sementara itu, hadits yang membicarakan tentang berlaku adil pada anak, dalam riwayat Imam al-Bukhari (2003: 341), dijumpai sanad dan matan selengkapnya sebagai berikut: 


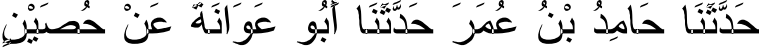

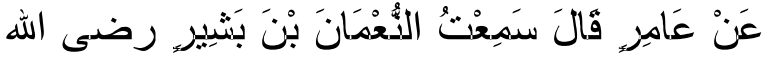

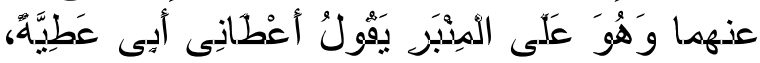

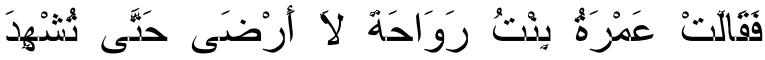

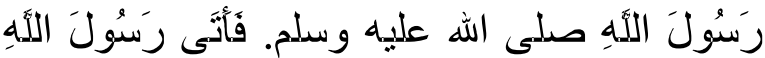

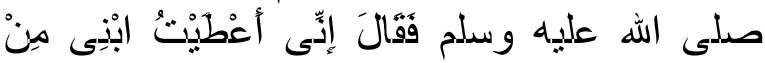

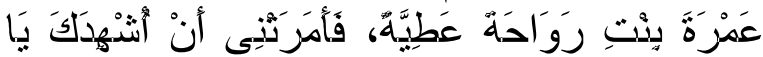

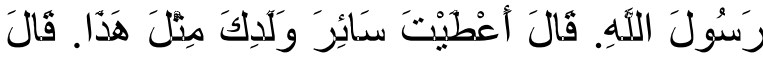

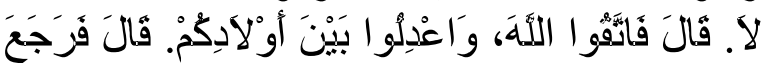

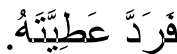

Adapun rangkaian nama-nama para periwayat hadits yang terungkap secara gamblang pada jalur periwayatan Imam al-Bukhari adalah dapat dilihat pada skema sebagai berikut:

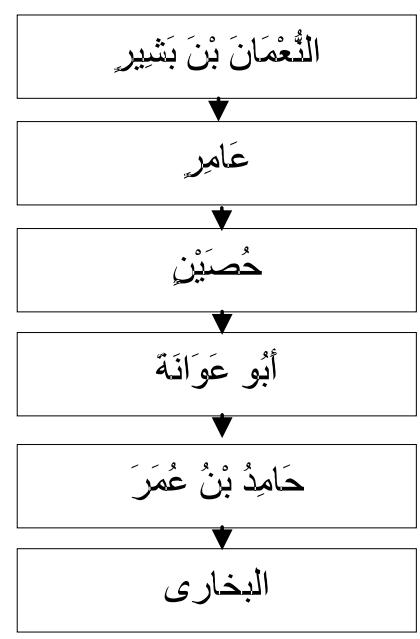

Sementara itu, hadits yang membicarakan tentang berlaku adil pada anak, dalam riwayat Imam Muslim (2003: 67), dengan sanad dan matan selengkapnya dapat dilihat sebagai berikut:

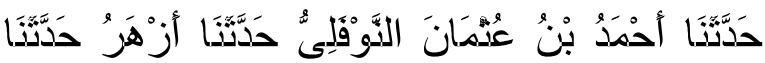

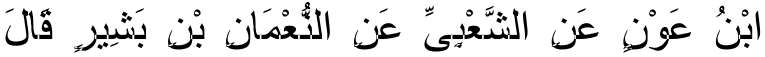

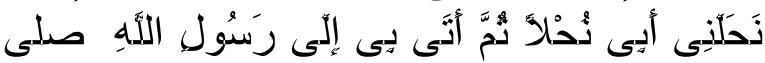

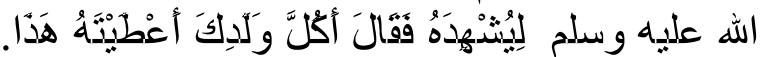

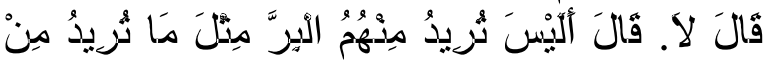

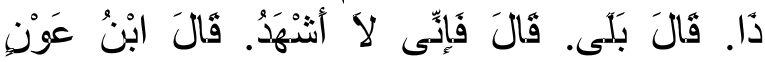

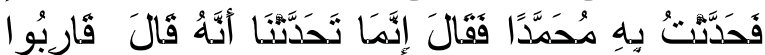

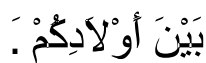

Adapun rangkaian nama-nama para periwayat hadits yang dapat diungkap pada jalur periwayatan Imam Muslim di atas adalah dapat dilihat pada skema sebagai berikut:

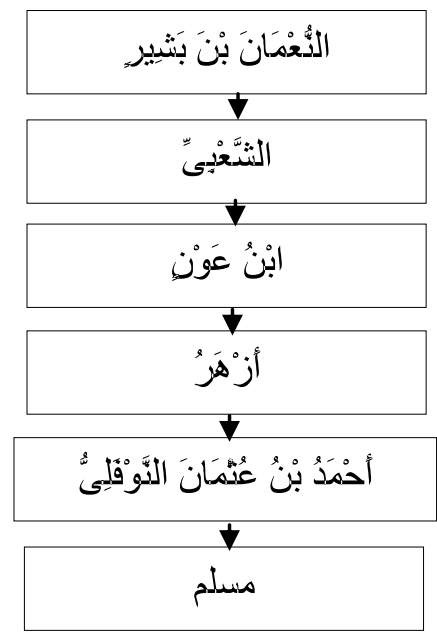

Sementara itu, hadits yang membicarakan tentang berlaku adil pada anak, dalam riwayat Imam al-Nasa'iy (2003: 262), sanad dan matan selengkapnya dapat dilihat sebagai berikut:

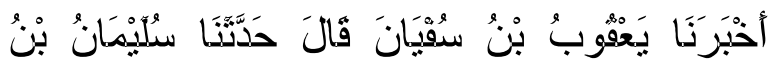

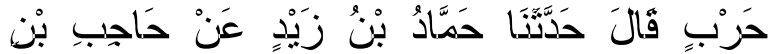

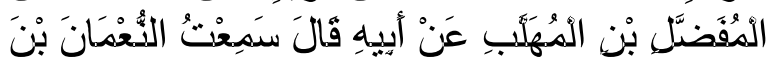

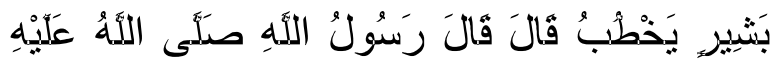

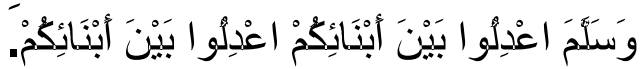

Adapun rangkaian nama-nama para periwayat hadits yang terungkap pada jalur periwayatan Imam al-Nasa'iy adalah dapat dilihat pada skema sebagai berikut:

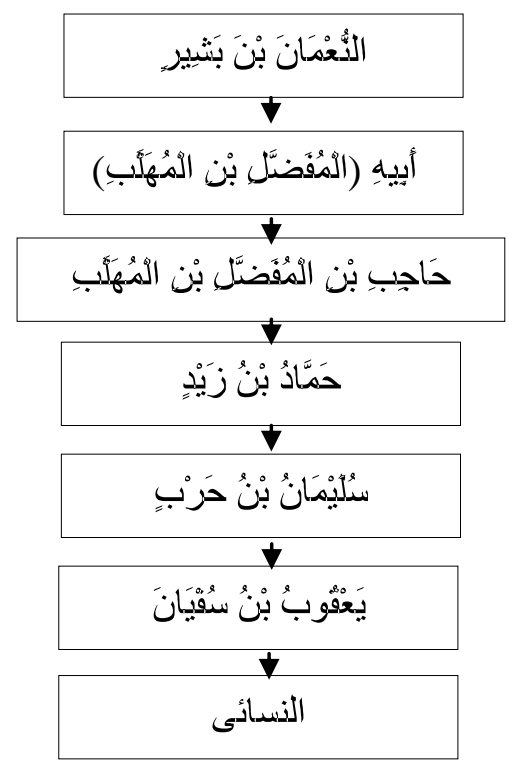


Sementara itu, hadits yang membicarakan tentang berlaku adil pada anak, dijumpai dalam riwayat Imam Ahmad (tt: 185), sanad dan matan selengkapnya dapat dilihat pada hadis berikut:

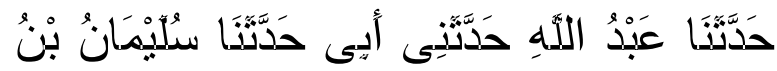

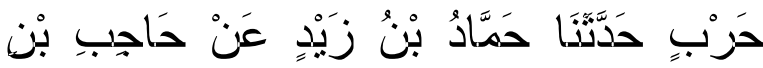

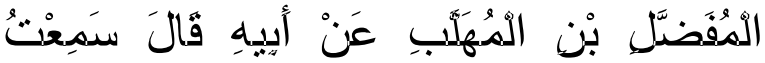

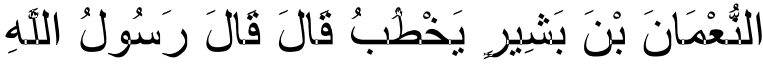

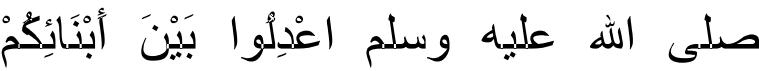

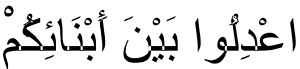

Adapun rangkaian nama-nama para periwayat hadits yang terungkap secara jelas pada jalur periwayatan Imam Ahmad, lebih jelasnya dapat dilihat pada skema sebagai berikut:

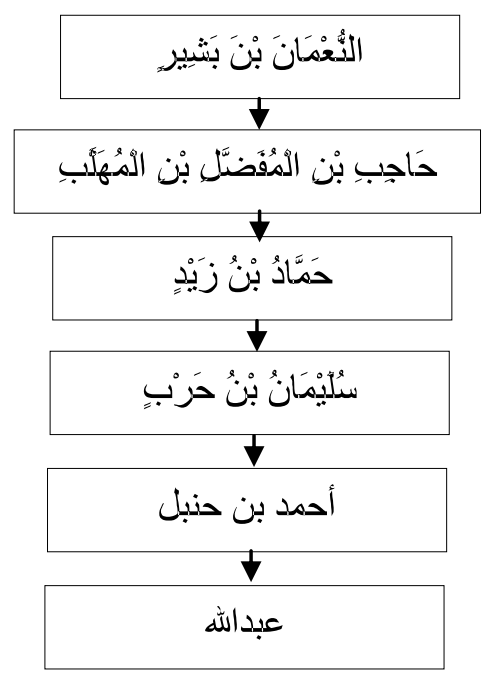

Berdasarkan uraian di atas dapat diketahui bahwa hadits tentang "berlaku adillah terhadap anak-anakmu," yang diriwayatkan oleh; Abu Dawud, Imam alBukhari, Imam Muslim, Imam al-Nasa'iy, dan Imam Ahmad, dengan rawiy al-a'la (periwayat terakhir di kalangan sahabat) adalah al-Nu'man bin Basyir ra. Dalam paper ini, jalur sanad/periwatan yang penulis takhrij, hanya pada jalur sanad/periwayatan Abu Dawud, Imam alNasa'iy dan Imam Ahmad, karena ketiga jalur memiliki kesamaan jalur periwayatan.

\section{PENJELASAN MAKNA MUFRADAT}

Kata أثنهد merupakan fi'l al-mudari' dari أثهر yang dapat ilihat akar katanya terlihat dari huruf د ش yang mana menunjukkan makna hadir, pengetahuan dan informasi (ibn Zakariya, 2002: 172). Kemudian diikutkan dengan wazan أثنهد (menambah huruf hamzah diawalnya) sehingga dapat diinterpretasi maknanya menjadi mempersaksikan atau membuat saksi (Mustafa, dkk, 2007: 1032).

Kata عطية merupakan bahasa Arab dimana yang berakar dari kata ${ }^{\prime}$ \& memiliki makna mengambil atau memperoleh sesuatu dengan tangan (Ibnu Hamzah, 2007: 287). Maka dengan demikian yang dimaksud dengan عطية adalah pemberian yang diberikan kepada orang lain, baik karena memulyakan atau tidak, baik ikhlas atau tidak, baik karena ingin mendapatkan pahala atau tidak (alAskari, 2000: 153).

Kata سائر adalah kata yang dapat digunakan pada pengertian sesuatu yang lain yang masih tersisa, di mana hampir باقى memiliki kesamaan maknanya dengan (sisa). Namun makna dasarnya adalah berlalu atau mengalir, sehingga dapat diinterpretasi bahwa yang dimaksud dengan سائر dalam hadits ini adalah anak yang terlewati yang tidak mendapatkan pemberian seperti apa yang didapatkan saudaranya (al-Askari, 2000: 153).

Kata فاتقو أتو berasal dari وقى yang dapat diartikan menghindarkan sesuatu dari sesuatu yang lain dengan yang lain (Ibnu Hamzah, 2007: 288). Sehingga al-wiqayah dimaknai dengan menjaga sesuatu dari hal-hal yang dapat menyakiti atau membahayakannya. Dengan demikian, kata al-taqwa secara etimologi adalah membuat al-wiqayah (penjagaan atau perlindungan), sedangkan secara termonologi adalah menjaga diri dari kemurkaan Allah SWT dengan taat kepada Allah SWT. Berdasarkan hal itu al-taqwa mencakup ketaatan yang berarti keikhlasan dan mencakup kemaksiatan 
yang berarti peninggalan atau pewaspadaan (al-Manawi, $1410 \mathrm{H}$ : 730).

Kata واعدلو pada dasarnya memiliki dua makna yang bertentangan, yaitu lurus dan bengkok. Jadi $a l$-'adl adalah ungkapan tentang sesuatu yang tengah-tengah antara semborono dan berlebih-lebihan. Sedangkan secara termonologi, para ulama berbeda pendapat. Ulama Nahwu mendefinisikan adil sebagai keluarnya isim dari sighat aslinya kepada sighat yang lain. Ulama Fiqh mendefinisikan bahwa orang yang menjauhi dosa-dosa besar, tidak terus menerus melakukan dosa kecil, sering benar dan menjauhi pekerjaan-pekerjaan yang merendahkan diri seperti makan di jalan (al-Jurjani, $1405 \mathrm{H}$ : 90). Sedangkan ulama Hadits mendefenisikan al-'adl sebagai sebuah sifat yang tertanam dalam hati yang dapat mendorong seseorang untuk senantiasa bertaqwa dan menjaga muruah (harga diri) (al-Jurjani, 1405 H: 91). Namun dalam hadits ini, yang dimaksud al-'adl adalah salah satu makna etimologinya yaitu lurus atau berada di tengah-tengah.

Kata أو لادكم merupakan bentuk plural (al-jam') dari ولد yang dapat dimaknai sebagai setiap anak yang dilahirkan, baik laki-laki maupun perempuan. Kata alwalad meskipun memiliki persamaan dengan al-ibn, al-sibt dan al-'aqab juga memiliki perbedaan (al-Afriqi, tt,: 467).

Berdasarkan hadits yang dikemukakan di awal dapat diuraikan makna ijmal hadits tersebut sebagai berikut: "Menceritakan kepada kami Sulaiman bin Harb, menceritakan kepada kami Hammad, dari Habib bin Mufadhdhal bin Muhallab, dari Bapaknya (Mufadhdhal bin Muhallab) berkata: Saya mendengar an-Nu'man bin Basyir berkata: Rasulullah SAW bersabda: Berlaku adillah diantara anak-anak kalian, berlaku adillah diantara anak-anak kalian". (HR. Abu Dawud).

Di samping itu terdapat hadits yang dikemukakan oleh Imam al-Bukhari dan Muslim yang memiliki kemiripan matan, yaitu: "al-Nu'man ibn Basyir ra., ketika dia di atas mimbar berkata "Ayahku memberikan sesuatu kepadaku," lalu 'Amrah binti Rawahah berkata "Saya tidak rela hingga engkau mempersaksikan hal tersebut kepada Rasulullah SAW.", lalu dia mendatangi Rasulullah SAW. seraya berkata "Saya telah memberikan sesuatu kepada putraku yang dari 'Amrah binti Rawahah, lalu ia menyuruhku mempersaksikan kepadamu wahai Rasulullah saw. lalu Rasulullah saw. berkata "Apakah engkau telah memberikan hal yang sama kepada anak-anakmu yang lain?", lalu Basyir menjawab "Tidak" lalu Rasulullah SAW., bersabda "Takutlah kalian kepada Allah dan berlaku adillah terhadap anak-anakmu". Lalu Basyir pulang kemudian mengambil kembali pemberiannya." (HR. al-Bukhari dan Muslim)

Hadits di atas-berlaku adillah di antara anak-anak kalianmenggambarkan bahwa semua orangtua diharuskan untuk memiliki sikap berlaku adil pada anak dalam hal bergaul dalam keluarga. Orangtua dituntut untuk memperlakukan anak-anak mereka dengan sikap adil dalam setiap pemberian, sikap, dan lainnya. Hal di atas menggambarkan bahwa orangtua harus memiliki etika bergaul dalam keluarga dengan memperlakukan anak-anak secara adil sesuai dengan konteks di atas. Dampak etika bergaul dengan sikap berlaku adil orangtua, akan membuat anak menghargai dan memiliki sikap kasih sayang diantara mereka dan juga kepada orangtuanya. Perilaku yang adil yang ditunjukan orangtua, memberikan kontribusi besar bagi perkembangan psikologis anak untuk berlaku yang sama dapat menempa dirinya menjadi pribadi yang amanah, jujur dan bertanggung jawab. Di samping itu akan melahirkan anak memiliki relationship yang baik dengan sesama, karena terbiasa dengan proses bergaul dengan prinsip keadilan dalam keluarga 
STATUS HADITS: ANALISIS TERHADAP STATUS SANAD DAN MATAN HADITS Persambungan Sanad

Al-Nu'man bin Basyir ra. (1-64 H.)

al-Nu'man bin Basyir memiliki nama lengkap al-Nu'man bin Basyir bin Sa'ad bin Tsa'labah bin Jallas bin Zaid bin Malik bin Tsa'labah, ibn Ka'ab ibnu al-Khazraj alAnshari al-Khazarijiy, Abu Abdillah alMadaniy (al-Asqalaniy, 2008: 399). Hidup pada tahun 1-64 H. Beliau adalah Sahabat Nabi yang lahir di Madinah setelah Nabi hijrah berjalan 4 bulan. al-Nu'man bin Basyir meriwayatkan hadits dari Rasulullah SAW. dan meriwayatkannya dari pamannya, Abdullah bin Rawahah, Umar bin al-Khattab dab A'isyah. Adapun para murid yang meriwayatkan hadits dari beliau adalah anaknya sendiri, Abdullah bin al-Nu'man, Mawalanya Hubaib bin Salim, al-Sya'bi, Ubaidillah bin bin Abdullah bin Utbah, Urwah bin Zubair, al-Muafaddal bin al-Muhallab bin Abi Shafra', Azhar bin Abdullah al-Harraziy, dan lain-lain (al-Asqalaniy, 2008: 399).

Tentang kualitas dan kredibilitas kepribadiannya tidak perlu diragukan lagi, karena ia adalah sahabat Anshar yang pertama kali setelah hijrah. Kemudian berdomisili di Syam dan wafatnya terbunuh di Desa Himash di negeri Syam pada bulan Dzulhijjah $64 \mathrm{H}$. Menurut Ibnu Abi Khaitsamah wafatnya pada tahun 60 H. Ayahnya yang bernama Basyir ini wafat sebagai syahid bersama Jenderal Khalid bin Walid pada tahun $12 \mathrm{H}$. setelah perang Yamamah. Beliau adalah Sahabat Anshar yang pertama kali berbai'at dengan khalifah Abu Bakar al-Shiddiq ra., dan ikut 'Aqabah Tsaniyah. Ikut perang Badar, Uhud dan semua perang yang diikuti beliau Nabi SAW (al-Asqalaniy, tt.: 440). Ia dalam meriwayatkan hadits dari Nabi SAW., semua berjumlah 114 buah hadits, yang antara hadits al-Bukhari dan Muslim ada 5, hadits yang diriwayatkan alBukhari saja hanya 1 , dan hadits yang diriwayatkan di Muslim saja ada 4 hadits (al-A'zhami, 1995: 89).
Al-Mufaddal bin Muhallab (w. 167 H.)

Nama lengkap al-Mufaddal: alMufaddal bin al-Muhallab bin Abi Shafra' al-Azadiy Abu Ghassan alBashri, tidak diketahui dengan pasti tahun kelahiran dan ia wafat pada tahun 167 H. Ia meriwayatkan hadits dari: alNu'man bin Basyir, dan murid yang meriwayatkan hadits darinya: anaknya sendiri, Hajib bin al-Mufaddal bin alMuhallab, Tsabit al-Bananiy, dan Jarir bin Hazim (al-Asqalaniy, tt,: 246).

Komentar para ulama terhadap kualitas dan kredibilitas al-Mufaddal bin al-Muhallab; قال إبحاق بن منصور و عباس الدوري (Ishaq bin Manshur dan Abbas al-Dauri berkata, bersumber dari Yahya bin Ma'in, Abu Zae'ah dan al-Nasa'i ,"al-Mufaddal bin alوقال أبو . Muhallab seorang yang tsiqah"). (Abu Hatim berkata, alMufaddal bin al-Muhallab seorang yang shuduq lagi tsiqah). وقال العجلي: كان ثقة، ثبتا (al-Ajaliy berkata, al-Mufaddal bin alMuhallab seorang yang tsiqah lagi tasubut) (al-Muzzy, tt,: 424).

\section{Hajib bin al-Mufaddal bin Muhallab}

Nama lengkap Hajib: Hajib bin alMufaddal bin Muhallab bin Abi Shafra'. Tidak diketahui tahun lahir dan tahun wafatnya. Ia meriwayatkan hadits dari : ayahnya, al-Mufaddal bin Muhallab, dan murid yang meriwayatkan hadits darinya, Hamad bin Zaid (al-Muzzy, tt,: 203). Komentar para ulama terhadap kualitas dan kredibilitas Hajib bin al-Mufaddal: قال إسحاق بن منصور ، عن بحيى بن محين: ثقة (Ishaq bin Manshur berkata, bersumber dari Yahya bin Ma'in, Hajib bin al-Mufaddal seorang ووثقه ابن حبان، والذهبي، و ابن حجز.Mang tsiqah) (Ibnu Hibban, al-Dzahabiy dan Ibnu Hajar menilainya sebagai seorang yang tsiqah) (al-Raziy, tt.: 284).

\section{Hamad bin Zayd (W. 179 H.)}

Nama lengkap Hamad: Hamad bin Zayd bin Dirham al-Azadiy al-Jahdhamiy, Abu Isma'il al-Bishri al-Azraq, Mawla Ali 
Jarir bin Hazim (al-Raziy, tt: 289). Ia meriwayatkan hadits dari: Hajib bin alMuhallab bin al-Muafaddal, dan lainlain. Sementara para murid yang meriwayatkan hadits darinya: Sulaiman bin Harb, dan lain-lainnya (al-Raziy, tt: 249). Komentar para ulama tentang kualitas dan kredibelitas: seluruh ulama memberikan pujian terhadap Hamad bin Zayd, sebagai berikut:

وقال سليمان بن أيوب صاحب البصري سدعت

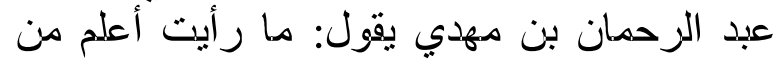

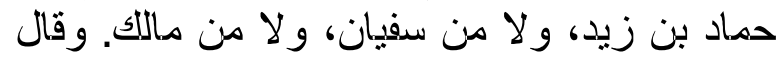

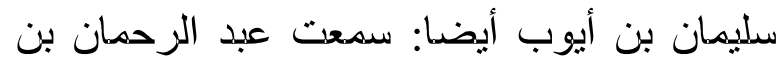
مهدي يقول: ما رأيت أحدا لم يكتب الحديث الحديث أحفظ

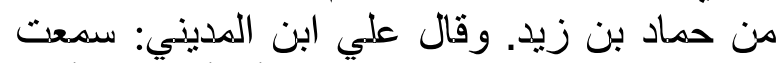

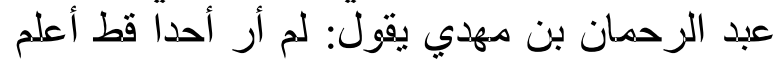

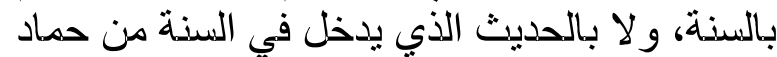

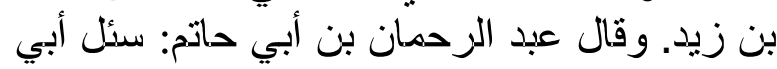

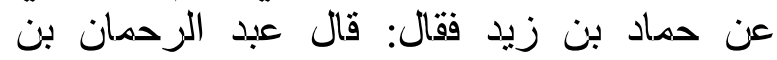
مهدي: ما رأيت بالبصرة أفقه من حماد بن زيد.

"Berkata Sulaiman bin Ayyub Shahib alBishri, Aku mendengar dari Abdurrahman bin Mahdiy, ia berkata "Tidak ada aku lihat orang yang lebih alim dari Hamad bin Zaid, tidak ada terlihat pada Sufyan dan juga pada Malik." Sulaiman bin Ayyub juga pernah berkata, Aku mendengar dari Abdurrahman bin Mahdiy, ia berkata "Tidak ada aku lihat seorangpun (ulama hadits) yang lebih kuat hafalannya yang tidak mencatat hadits dari Hamad bin Zaid." Berkata Ali bin al-Madiniy, Aku mendengar Abdurrahman bin Mahdiy berkata, Aku belum pernah melihat seseorang yang lebih alim tentang Sunnah dan Hadits dari Hamad bin Zaid. Berkata Abdurrahman bin Abi hatim, Ayahku pernah ditanya tentang Hamad bin Zaid, berkata Abdurrahman bin Mahdiy, "Tiada aku lihat seseorang yang lebih faqih di Bashrah melebihi Hamad bi Zaid" (alRaziy, tt: 244).

\section{Sulaiman bin Harb (140-224 H)}

Nama lengkap Sulaiman: Sulaiman bi Harb bin Bajil al-Azadiy al-Wasyihi, Abu Ayyub al-Bashriy (al-Raziy, tt.: 150), dilahirkan pada tahun $140 \mathrm{H}$ dan wafat tahun $224 \mathrm{H}$ (al-Asqalaniy, tt.: 158). Ia meriwayatkan hadits dari: Syu'bah, Muhammad bin Thalhah, Hammad bin Zayd, dan lain-lain. Sementara para murid yang meriwayatkan hadits darinya: alBukhari, Muslim, Ibnu Majah, Abu Dawud, al-Turmudzi, al-Nasa'i, Ahmad, dan lain-lain (al-Mizziy, tt.: 145). Komentar para ulama: وقال ابن سعد كان ثقة كثير الحديث (Ibnu Sa'ad berkata, Sulaiman bin Harb adalah seorang yang tsiqat, seorang yang banyak menghafal hadits), وقال ابن قانع ثقة مأمون Ilbnu Qani' berkata, Sulaiman bin Harb seorang yang tsiqat, lagi dipercaya), روى عنه البخاري مائة وسبعة وعثرين حديثا (alBukhari meriwayatkan hadits dari Sulaiman bin Harb sebanyak 127 hadits) (al-Mizziy, tt.: 158).

\section{Ya'qub bin Sufyan (W. 277 H.)}

Nama lengkap Ya'qub bin Sufyan adalah Ya'qub bin Sufyan bin Jauban alFarisiy, Abu Yusuf bin Abi Mu'awiyyah, alFasawiy al-Hafizh, wafat pada tahun 277 $\mathrm{H}$ (al-Asqalaniy, tt.: 338). Ia meriwayatkan hadits dari: Hibban bin Hilal, Abi Ashim alNabil, Abi Nu'aim al-Fadhl bin Dakin, Sulaiman bin Harb, dan lain-lain. Sementara para murid yang meriwayatkan hadits darinya: alTurmudzi, al-Nasa'iy, dan lain-lain (alMizziy, tt.: 325).

Komentar para ulama terhadap kualitas dan kredibelitas Ya'qub bin Sufyan: seluruh ulama memberikan pujian kepadanya, sebagai berikut Al-Mizziy, tt.: 331):

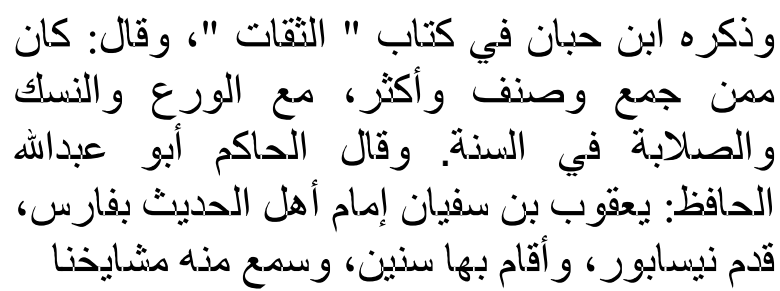


Ibnu Hibban menyebutkan dalam kitabnya al-Tsiqah, dan ia berkata bahwa Ya'qub bin Sufyan termasuk ulama yang multi dan mumpuni di bidangnya ; penyusun kitab yang cukup banyak, seorang yang wara', ahli ibadah, dan pembela Sunnah. Berkata al-Hakim Abu Abdullah al-Hafizh bahwa Ya'qub bin Sufyan adalah Imamnya Ahl al-Hadits mulai dari Persia sampai ke Naisabur, dia menggeluti bidang hadits selam bertahuntahun dan banyak para ulama yang belajar kepadanya.

\section{Kualitas Sanad dan Matan}

Hadits Nabi Muhammad SAW tentang "berlaku adillah terhadap anakanakmu," dapat dijelaskan bahwa ditinjau dari sumber/sandaran berita, hadits ini marfu', yaitu hadits yang sumber beritanya sampai kepada Nabi SAW (alTirmiziy, 1994: 8), di mana rawiy al-a'la hadits ini adalah al-Nu'man bin Basyir ra. Ditinjau dari segi kuantitas sanad (jumlah periwayat), hadits ini termasuk Ahad, yang Aziz (1 orang periwayat dari kalangan sahabat) dan tidak sampai ke peringkat Mutawatir. Walaupun sanad hadits/jalur periwayatannya memiliki banyak jalur, akan tetapi pada tiap thabaqah sanad hadits ini tidak mencapai jumlah periwayat yang disyaratkan dalam hadits Mutawatir (al-Ahdali, 1990: 95; alKhatib, 1989: 301).

Sementara dari segi kualitas sanad, hadits tersebut jika dilihat dari kriteria keshahihan hadits dapat dijelaskan sebagai berikut (al-Khatib, 1989: 302): Pertama, bersambung sanad (ittishal sanaduh), hal ini ditandai dengan adanya indikator bahwa antara para periwayat yang satu dengan yang lainnya sebagai guru dan murid pernah bertemu (liqa'), di mana nama-nama guru dan murid tercatat dalam biografi masing-masing (rawa 'an dan rawa anhu). Di samping itu, antara guru dan murid pernah hidup dalam suatu masa (mu'asharah), diketahui dari tahun kelahiran/wafat. Dengan demikian hadits tersebut terindikasi kebersambungan dan kebersandarannya sampai kepada Rasulullah SAW (muttashil dan marfu'). Kedua, keseluruhan periwayat dalam sanad tersebut mayoritas menunjukkan bahwa mereka adalah para periwayat yang adil dan dhabith (tsiqah), dan tidak ditemukan kecacatan (tajrih) yang dikemukakan oleh ulama kritikus hadits. Ketiga, dalam sanad dan matan hadits tidak ditemukan adanya kejanggalan (syudzudz) dan tidak ada cacat ('illat).

Dengan demikian hadits tentang "berlaku adillah terhadap anak-anakmu," yang diriwayatkan oleh Abu Dawud, alBukhari, Muslim, al-Nasa'iy dan Ahmad ini dinilai sebagai hadits yang berkualitas shahih. Hal ini sejalan dengan hasil penelitian Syaikh Muhammad Nashiruddin al-Baniy terhadap hadits قال الثيخ الألباني : : (Syaikh al-Baniy berkata, hadits ini berkualitas shahih) (al-Baniy, 2007: 215).

\section{SYARAH FIQH PENDIDIKAN HADITS Pengertian Judul: Bahasa dan Istilah}

Melacak makna substansial dari masalah krusial pembahasan dalam tulisan ini-sesuai dengan judul papermaka akan mengarah pada dua hal utama yaitu etika bergaul dalam keluarga dan sikap berlaku adil orangtua pada anak.

Etika dalam kajian Islam mengandung kesamaan makna dengan akhlak (Mifka, 2011: 115). Khusus dalam kajian etika Islam, akhlak lazimnya dipakaikan untuk moral, sedang 'ilmu alakhlaq untuk etika atau filsafat moral. Jadi, etika merupakan perilaku moral aktual yang hidup dalam diri manusia setelah upayanya menumbuhkan perilaku moral potensial yang telah Allah SWT anugerahkan kepadanya (Harmakaputra, 2015; Amril, 2005: 10). Etika Islam atau akhlak tidak dapat dipisahkan dengan sifat-sifat terpuji, bahkan dihubungkan dengan Allah SWT. Sedemikian rupa sifatsifat Allah ini diinginkan dan diperintahkan oleh Allah SWT terjalin 
dalam setiap perilaku manusia dalam aktivitas kesehariannya. Al-Qur'an dan alSunnah menjadi sumber utama nilai perilaku etika (Tambak, Amril, Khairi, \& Sukenti, 2018; Amril, 2005: 12). Maka, etika bergaul dalam keluarga dimaksudkan adalah perilaku moral aktual yang diterapkan dan dibudayakan orangtua dalam keluarga saat bersosiasialisasi, berhubungan, dan berinteraksi dengan anak sesuai dengan potensi yang telah Allah anugerahkan kepadanya. Etika ini terkait dengan perilaku yang baik sesuai dengan standard yang digariskan dalam ajaran Islam di mana orangtua berinteraksi dengan anak. Saat terjadi interaksi itu haruslah mengandung nilai-nilai Islami yang baik antara orangtua dan anak di lingkungan keluarga. Interaksi yang dibangun dan dibudayakan berdasarkan nilai-nilai Qur'ani oleh orangtua, akan membuat anak tumbuh dan berkembang dengan suasana nyaman, damai, bertanggung jawab, dan mandiri.

Sikap berlaku adil orangtua pada anak dapat dilacak pada hadits yang telah ditakhrij sebelumnya. Merujuk pada apa yang telah dikemukakan sebelumnya bahwa kata واعدلوا pada dasarnya memiliki dua makna yang bertentangan, yaitu lurus dan bengkok (al-Jurjaniy, $1405 \mathrm{H}$ : 90). Adil berarti "tidak berat sebelah atau memihak", "berpihak serta berpegang pada kebenaran", "tidak sewenangwenang atau zalim", dan 'seimbang serta sepatutnya". Kata adil mempunyai banyak makna, bahkan salah satu dari 99 dari nama Allah SWT (asma al-husna) adalah al-'adl (Azra, 2005: 82).

Said bin Jabir, seorang ulama hadits, mengatakan bahwa al-'adl mempunyai empat pengertian. (1) Dalam bidang hukum, adil berarti "berlaku adil". (2) Dalam perkataan, adil berarti benar dan jujur. (3) Adil berarti tebusan. (4) Adil juga berarti kemusyrikan (azra, 2005: 82). Di samping al-'adl, dalam bahasa Arab digunakan juga kata al-'idl. Dalam bahasa
Indonesia dua kata ini mempunyai arti yang sama, yakni keadilan. Namun dalam bahasa Arab keduanya digunakan dalam perkara yang berbeda. Kata al-'adl digunakan dalam perkara keadilan yang menggunakan kalbu dan rasio sebagai ukurannya. Adapun kata al-'idl digunakan dalam kasus yang dapat dipantau dengan pancaindra, seperti timbangan, hitungan, dan ukuran. Dalam mengukur dan menimbang, keadilan berarti "kesesuaian dengan ukuran yang sebenarnya". Dalam pembagian, keadilan berarti "kesamaan antara bagian-bagian dari barang yang dibagi”. (Azra, 2005: 82).

Makna yang adil ini kemudian menjadikan perluasan pemahaman dalam upaya merekonstruksi sikap untuk orangtua pada strategi etika bergaul yang baik dalam hal keadilan pada anak-anak dalam keluarga. Imam Syafi'i berpendapat bahwa adil berarti "dapat dipercaya dalam bidang agama, benar dalam berbicara, dan tidak berbohong". Akan tetapi adil dalam pengertian ini bukan bahwa orang yang memiliki sidat itu sama sekali bebas dari dosa, karena tidak ada manusia yang demikian terjaga (Azra, 2005: 83; Ahmad \& Tambak, 2017). Orang yang tidak adil adalah orang zalim, baik bagi dirinya maupun dan terutama bagi orang lain. Berbuat zalim terhadap orang lain (fahisyah) teramasuk diosa besar. Oleh karena itu, orang yang tidak berlaku adil diancam dengan siksa yang berat di akhirat. Di dunia, orang yang tidak adil, sebgaiman pelaku dosa besar lainnya, diperlakukan sebagai orang fasik, yaitu tidak bileh diangkat menjadi penguasa (pejabat) dan hakim. Di samping itu, riwayat (hadits), kesaksian, dan kewaliannya tidak diterima (Azra, 2005: 83).

Hal di atas menggambarkan bahwa orangtua harus memiliki etika bergaul dalam keluarga dengan memperlakukan anak-anak secara adil sesuai dengan konteks di atas. Dampak etika bergaul dengan sikap berlaku adil orangtua, akan 
membuat anak menghargai dan memiliki sikap kasih sayang diantara mereka dan juga kepada orangtuanya. Perilaku yang adil yang ditunjukan orangtua, memberikan kontribusi besar bagi perkembangan psikologis anak untuk berlaku yang sama dapat menempa dirinya menjadi pribadi yang amanah, jujur dan bertanggung jawab. Di samping itu akan melahirkan anak memiliki relatioanship yang baik dengan sesama, karena terbiasa dengan proses bergaul dengan prinsip keadilan dalam keluarga.

\section{Penjelasan Asbab al-Wurud}

Asbab al-wurud hadits ini adalah peristiwa yang menimpa al-Nu'man bin Basyir, yaitu ketika ayahnya (Basyir) memberikan sesuatu kepadanya, kemudian 'Amrah binti Rawahah (Ibunya al-Nu'man) komplain dengan mengatakan "Aku tidak rela terhadap pemberian itu hingga disaksikan oleh Rasulullah SAW., kemudian ayahnya datang kepada Rasulullah SAW., seraya berkata "Aku telah memberi harta kepada anakku ini" Rasulullah SAW., bertanya "Apakah seluruh anakmu telah kau telah beri (hal yang sama)?" lalu ayah al-Nu'man menjawab "Tidak." Rasulullah SAW., bersabda "Kembalilah kamu, takutlah kepada Allah dan berlaku adillah terhadap anak-anakmu." al-Nu'man bin Basyir berkata "Akhirnya ayahku pulang dan dia membatalkan pemberiannya itu" (alDimasyqi, 2006: 32).

Dalam riwayat yang lain, al-Nu'man berkata "Ibuku 'Amrah binti Rawahah meminta kepada ayahku pemberian harta untukku yaitu seorang budak (al-gulam), kemudian permintaan itu dipenuhi setelah hampir dua tahun, kemudian ibuku tidak rela kalau tidak disaksikan oleh Rasulullah SAW., Akhirnya ayahku membawaku kepada Rasulullah SAW., lalu menjelaskan pemberian itu, kemudian dijawab oleh Rasulullah seperti jawaban yang telah dijelaskan sebelumnya (alAsqalaniy, 2003: 212). Dalam kisah yang lain, yaitu pada saat al-Nu'man khutbah di kota Kufah, dia berkata sesungguhnya ayahku datang kepada Nabi saw. dan berkata bahwa 'Amrah binti Rawahah melahirkan seorang putra yang kuberi nama al-Nu'man dan 'Amrah tidak mau mengasuhnya hingga anak tersebut diberi kebun yang paling baik dari kebunku, lalu Rasulullah SAW. bertanya seperti pertanyaan di atas (al-Asqalaniy, 2003: 212).

Perbedaan riwayat tentang asbab alwurud hadits ini, dapat dikompromikan bahwa kasus pemberian Basyir terhadap anaknya al-Nu'man terjadi dua kali, yaitu pemberian kebun pada saat lahir dan pemberian budak pada saat ia anak-anak. Kebun yang telah diberikan kepada alNu'man diambil kembali oleh ayahnya karena dia tidak memberikan kebun kepada anaknya yang lain. Oleh karena itu, 'Amrah (ibu al-Nu'man) meminta kembali pemberian sebagai ganti kebun tersebut, kemudian Basyir memenuhi permintaan istrinya lalu dia memberikan budak kepada anaknya, akan tetapi 'Amrah meminta agar pemberian itu disaksikan oleh Rasulullah SAW., agar pemberian itu tidak diambil kembali oleh ayahnya (alDimasyqi, 2006: 32).

\section{Pemahaman Hadits: Pendapat Ulama Fiqh dan Ushul Fiqh}

Dalam memahami hadits tersebut ulama hadits berbeda pendapat dalam memberikan penjelasan, sebagai berikut: Pertama, sebagian ulama, di antaranya alBukhari, Thawus, Sufyan al-Tsauri, Ahmad ibn Hanbal dan Ishaq bin Rawaih memahami hadits tersebut secara tekstual yakni wajib menyamakan pemberian terhadap anak, baik laki-laki maupun perempuan. Alasan mereka adalah kandungan teks hadits itu sendiri dan kaidah التحريم حرام ما يؤدى إلى (sesuatu yang menimbulkan keharaman menjadi haram) di mana ketidaksamaan pemberian terhadap anak dapat memutus silaturrahmi, persuhan dan 
pembangkangan terhadap orangtua (alAsqalaniy, 2003: 214). Akan tetapi ulama beragam tentang kualitas dan kuantitas penyamaan pemberian: (1)Muhammad ibn al-Hasan, Ahmad, Ishaq dan ulama yang lain menilai penyamaan tersebut harus mengikuti pembagian warisan, karena itulah hak anak pascawafatnya orangtua, (2) Ulama yang lain mengatakan bahwa penyamaan pemberian tidak membedakan antara laki-laki dan perempuan dengan melihat teks hadits tersebut, di samping itu ada hadits dari 'Abdullah ibn 'Abbas: بين أو لادكم في العطية سووا فلو كنت مفضدا أحدا لفضلت النساء (Berlaku samalah kepada anak-anak kalian dalam pemberian, Andaikan aku mengunggulkan seseorang maka aku akan unggulkan perempuan) (al-Baihaqi, 1994: 177).

Kedua, mayoritas ulama hadits menilai bahwa penyamaan pemberian itu bersifat sunat, bukan wajib sehingga jika seseorang membedakan pemberian terhadap anaknya maka hukumnya makruh, sehingga perintah dalam hadits tersebut bersifat sunnah dan larangan membedakan pemberian terhadap anak bersifat makruh (al-Mubarakfuri, tt.: 507).

Sementara ulama fiqh dalam menanggapi hadits tersebut di atas, beragam dalam memberikan pendapat, ada yang menganggap bahwa menyamakan pemberian terhadap anak sebagai anjuran saja bukan kewajiban dan ada yang menilainya sebagai kewajiban (al-Andalusi, tt.: 651), sehingga haram membeda-bedakan anak dalam pemberian dan kebaikan karena hal itu dapat menimbulkan permusuhan dan kebencian di antara mereka atau kepada orangtua. Namun mayoritas ulama fiqh sepakat sunnah menyamakan pemberian terhadap anak dan makruh membedabedakannya (al-Sabiq, tt.: 544). Meskipun demikian, ulama fiqh tetap berbeda pendapat tentang kualitas dan kuantitas pemberian terhadap anak sebagai berikut:

Pertama, Abu Yusuf dari mazhab alHanafiyah, al-Malikiyah dan al-Syafi'iyah (jumhur al-ulama) berpendapat bahwa disunnatkan menyamakan pemberian terhadap anak, baik laki-laki maupun perempuan berdasarkan hadits Rasulullah saw. di atas tanpa menyebutkan perbedaan laki-laki dan perempuan dengan menganggap perintah dalam hadits tersebut bersifat anjuran, karena seseorang bebas menafkahkan hartanya, baik kepada keluarga atau orang lain (alZuhaili, 1997: 651). Kedua, Al-Hanabilah dan Muhammad dari mazhab al-Hanafiyah berpendapat bahwa pemberian terhadap anak-anak disesuaikan dengan aturan warisan, sehingga laki-laki akan mendapatkan dua kali lipat dari perempuan (al-Zuhaili, 1997: 652).

Dengan melihat penjelasan ini beserta argumen-argumennya, baik dari aspek pemahaman teks dan konteks, dalil 'aqliah dan naqliah dan pendapat para ulama, dapat diinterpretasi bahwa penyamaan pemberian terhadap anak merupakan sunnah muakkad (sangat dianjurkan) karena beberapa alasan; (1) Untuk menghindari kecemburuan dan permusuhan dalam internal anak-anak, sekaligus untuk menghindari pembangkangan anak terhadap orangtua karena merasa terzalimi atau dibedakan; (2) Keluar dari perbedaan di kalangan ulama antara ulama yang mewajibkan menyamakan pemberian dengan ulama yang membolehkan pemberian yang berbeda dengan berdasar pada kaedah mazhab Syafi'iy:الخروج من الخلاف مستحب (alNawawi, 2000: 376).

Di samping itu, penyamaan pemberian juga bisa menjadi solusi penyelesaian dalam masalah warisan di mana banyak kalangan menentang terhadap pembagian warisan yang membedakan antara laki-laki dan perempuan dengan catatan pemberian itu diberikan sebelum meninggal. Sebab dalam al-'at\}iyyah atau al-hibah (pemberian) pada saat masih hidup dapat dibagi adil kepada anak-anak tanpa membedakan laki-laki dan perempuan. 
Meskipun demikian, penyamaan pemberian tidak harus sama dalam kualitas dan kuantitasnya, akan tetapi pemberian itu memperhatikan kebutuhan dan lapangan kerja anak-anak, semisal anak yang sudah mapan penghasilannya tidak mesti sama bagiannya dengan anak yang belum memiliki pekerjaan yang mapan. Di samping memperhatikan kebutuhan dan lapangan kerja, pemberian materi terhadap anak-anak tetap mempertimbangkan jenis kelamin, yakni perempuan bagiannya tidak lebih banyak dari pada bagian laki-laki sehingga tidak menimbulkan masalah di kemudian hari.

\section{Nilai-Nilai Pendidikan yang Terkandung dalam Matan Hadits}

Hadits tentang perilaku orangtua untuk berlaku adil pada anak-anaknya di atas dapat didinterpretasi menjadi empat hal utama sebagai nilai-nilai pendidikan; pendidikan kesetaraan; pendidikan kasih sayang; pendidikan demokratis; dan pendidikan kerukunan. Keempat hal ini menjadi bagian analisis penting untuk dikaji agar memberikan gambaran substantif bagi orangtua dalam bergaul di keluarga bersama dengan anak-anak mereka.

\section{Pendidikan Kesetaraan dalam Keluarga}

Anak merupakan amanah dari Allah SWT, sebagai amanah, ia harus dipelihara, diberi bekal hidup dan didik agar kelak menjadi manusia dewasa secara fisik dan mental (Azra, 2005: 177). Ia berhak memperoleh perlindungan dari semua yang dapat menghambat, apalagi merusak perkembangan secara jasmani maupun rohani. Orang tua berkewajiban memfasilitasi perkembangan diri anak dengan baik termasuk menciptakan suasana bergaul yang baik diantara sesama anak dalam hal perilaku adil (Lubis, 2016).

Merujuk kepada hadits yang dikemukakan dapat diinterpretasi bahwa berlaku adil kepada anak dapat memberikan nilai pendidikan kesetaraan. Dengan menerapkan sikap berlaku adil orangtua dalam bersosialisasi di lingkungan keluarga, membuat anak merasa dihargai dan memandang bahwa orangtua memperhatikan mereka secara maksimal. Mereka merasa akan diperlakukan sama akibat perilaku adil orangtua dalam kehidupan sehari-hari. Orangtua memperlakukan anak setara dengan lainnya dalam segala aspek kehidupan di keluarga. Orangtua tidak membeda-bedakan pemberian-seperti yang terkandung dalam hadits di atasantara laki-laki dan perempuan.

Sikap tidak adil atau pilih kasih antara laki-laki dan perempuan sangat perlu dihindari orangtua dalam pergaulannya dengan anak-anaknya, karena hal itu berdampak buruk pada anak di kemudian hari. Hal ini dapat dilihat pada hadits di atas yang menggambarkan bahwa para orangtua tidak diperkenankan membeda-bedakan gender dalam hal pemberian hadiah atau apapun pada anak-anaknya. Octavia (2012) memandang bahwa anak perempuan harus diperlakukan sama dengan anak laki-laki tanpa membedabedakannya. Ahmad Syarifuddin mengatakan bahwa tidak diperkenankan melebihkan satu anak terhadap anak lainnya atas dasar jenis kelamin (gender) (Syarifuddin, 2004: 100).

Maka orangtua dituntut untuk membesarkan anak di lingkungan keluarga dengan sebaik-baik perlakuan. Tidak membeda-bedakan hak dan kewajiban di antara laki-laki dan perempuan, semuanya harus diperlakukan dengan sama dalam prinsip keadilan (Azra, 2005: 74). Membiasakan hubungan sosialisasi pada anak dengan sebaik-baik perlakuan, kelak anak itu akan belajar tentang makna keadilan dan besar dengan nilai itu, baik dalam keluarga maupun masyarakat. Anak yang diajarkan nilai-nilai keadilan dalam bergaul di keluarga akan menimbulkan rasa aman. 
Anak yang dibesarkan dengan rasa aman dalam keluarga, kelak dia akan belajar menaruh kepercayaan dalam hidupnya.

\section{Pendidikan Kasih Sayang dalam Keluarga}

Berlaku adil pada anak-seperti hadits di atas-dapat memberikan rasa kasih sayang pada diri orangtua terhadap anak. Hal ini dapat dilihat dari pengembangan perilaku adil orangtua yang memperlakukan anak sama dalam keluarga. Orangtua tidak memihak, tidak berat sebelah, dan tidak membedabedakan anak dalam segala aspek kehidupan, dapat mendorong munculnya kasih sayang di antara anak dan orangtua, karena mereka merasa diperhatikan dan diperlakukan dengan baik (Irawan, 2017). "Menyayangi anak ialah mengajari anak sesuai dengan jenjang dan kapasitas kemampuan anak. Tidak membebani anak dengan muatan di luar kemampuannya" (Azra, 2005: 101).

Jika anak dibesarkan dengan kasih sayang dan persahabatan, maka kelak dia belajar menemukan cinta dalam kehidupan. Maka, sikap kasih sayang perlu dikembangkan dan ditanamkan pada anak sejak kecil dalam keluarga, dan ini pulalah masalah penting yang perlu diperhatikan oleh orangtua (Qaimi, 2002: 16). Bapak dan ibu dalam mencintai dan menyayangi anak-anaknya tidak dibenarkan bersikap pilih kasih; karena ini secara alami akan menyebabkan hilangnya kehormatan mereka dan hilangnya kepercayaan anakanak terhadap lingkungan keluarganya (Rahmatullah, 2017). Nabi Muhammad SAW menekankan pentingnya menjaga persamaan dan tidak bersikap pilih kasih dalam menunjukkan kasih sayang seperti dalam hadits di atas.

Oleh karena itu, menjaga kasih sayang dengan nilai-nilai keadilan dengan persamaan di antara anak-anak dalam keluarga adalah hal yang penting dan ketika hal itu tidak diperhatikan akan memberikan efek negatif. Menurut Qaimi
(2002: 18), ayah merupakan simbol keadilan, ibu merupakan simbol kasih sayang, di mana keduanya akan memperhatikan masalah merawat dan mengasuh anak. Di sini menggambarkan bahwa kasih sayang yang terbangun dari nilai-nilai keadilan dapat membawa harmonisasi antara anak dan orangtua dalam keluarga. Bila hal ini telah terbentuk dan terealisasi dengan baik, maka akan melahirkan generasi gemilang yang rabbani di masa yang akan datang.

Kasih sayang akan mendatangkan kesenangan dan kegembiraan. Semakin besar kasih sayang orangtua pada anak maka kegembiraan pada anak semakin besar dan menjadikan hati anak semakin peduli dan perhatian. Anak belajar kasih sayang dari orangtuanya dalam keluarga, sehingga ia akan menerapkan kasih sayang tersebut kepada orang lain dengan cara yang dilihatnya dari orangtuanya (Azra, 2005: 71). Anak yang tidak merasakan kasih sayang yang hakiki di samping mendapatkan pengaruh negatif pada tubuh dan jiwanya, juga akan bermasalah dalam mempelajari kasih sayang dan akhirnya ia tidak mampu mencintai dan menyayangi orang lain di masa yang akan datang.

Kasih sayang akan memunculkan kepercayaan dalam diri anak. Anak yang memiliki kemerdekaan dan kepercayaan diri mampu memecahkan persoalan sendiri dan tidak menunggu bantuan orang lain. Dengan motivasi besar dan tekad yang membaja, anak tersebut berusaha mencari solusi atas setiap problem yang dihadapinya, sehingga sebelum mencapai tujuannya maka pantang baginya untuk mundur. Di samping itu, kasih sayang akan memotivasi anak-anak untuk melakukan pelbagai aktivitas dengan sukses. Anak yang merasakan kasih sayang secara cukup maka ia akan sukses dalam menggeluti pelbagai aktivitas dan bidang yang digemarinya. Di bidang pendidikan ia akan menjadi anak yang cerdas dan 
terampil dan secara fisik pun ia akan tumbuh secara sehat. Kasih sayang kepada anak mampu menarik simpati sang anak, dan pada giliranya anak akan mempercayai ayahnya, sehingga terjalinlah hubungan baik antara keduanya dan anak akan mendengar dan menuruti perkataan sang ayah. Dengan demikian anak ini akan mudah dididik dan diarahkan oleh ayahnya. Sebab anak ini menyukai orang yang penyayang dan yang memahami keinginannya dimana orang seperti ini ia temukan pada pribadi ayahnya, sehingga ia akan menuruti perintah ayahnya.

\section{Pendidikan Demokrasi bagi Anak dalam Keluarga}

Perlakuan adil yang diterapkan orangtua dalam keluarga pada anakanaknya dapat memupuk suasana demokratis dalam jiwa anak (Ubaedillah \& Razak, 2008: 43; Rahman, 2018). Sebagai konsekuensi dari sikap adil, orangtua tidak pilih kasih dan memperhatikan hakhak anak akan memupuk sikap demokratis dalam keluarga. Karena dalam perilaku adil itu, terkandung nilai demokrasi (Saputra, 2017; Musmualimin \& Miftah, 2016) yang menjadi dasar bagi sikap dan perbuatan anak. Hubungan orangtua dengan anak dalam suasana keadilan akan berkembang karena menghargai hak-hak anak secara universal. Di sinilah nilai-nilai pendidikan demokratis itu tergambar, di mana seluruh anggota keluarga menghargai hak-hak anggotanya (Ahyar, 2017) sebagai akibat dari perilaku orangtua yang selalu mengedapankan nilai-nilai keadilan dalam bergaul di keluarga.

Dalam keluarga yang harmonis, kedua orangtua menganggap anak-anak mereka sebagai bagian dari dirinya. Asas dan dasar hubungan yang dibangun dengan anak-anak mereka adalah penghormatan, penjagaan hak-hak, pendidikan dan bimbingan yang layak, pemurnian kasih saying, serta pengawasan terhadap akhlak dan perilaku anak (Shidiq, 2015). Kedua orangtua benar-benar menjaga dan memperhatikan anak dengan kelembutan dan kasih sayang dan berusaha melenyapkan berbagai kekurangan yang ada padanya diri mereka (Qaimi, 2002: 18; Mukodi, 2016). Di sinilah dasar nilai-nilai Pendidikan demokrasi itu akan tertanam dengan baik pada diri anak dalam proses pergaulan di lingkungan keluarga.

Demokrasi bisa tertanam dalam diri anak dan juga bisa tumbuh dan berkembang dalam kehidupan keluarga jika ada keteladan dari orangtua. Di samping itu juga perlu pembelajaran dan pembudayaan nilai-nilai demokrasi secara terencana, bertahap, dan berkesinambungan. Di keluarga nilai-nilai demokrasi perlu ditanamkan sejak dini, agar anak kelak menghargai orang lain, tidak main hakim sendiri, menyadari bahwa orang lain juga memiliki kebebasan untuk berekspresi dan itu harus dihormati. Sebab, dalam perlakuan adil tersebut harus juga terdapat sifat saling menghargai dan mengakui bahwa semua orang memiliki kebebasan untuk berekspresi.

\section{Pendidikan Kerukunan bagi Anak}

Mengkaji hadits yang dikemukan sebelumnya, dapat diinterpretasi bahwa perilaku orangtua berbuat adil kepada anak dalam pergaulan sehari-hari di lingkungan keluarga dapat menciptakan kerukunan bagi anggota keluarga. Kerukunan ini, khususnya, antara anak dengan anak dan juga antara anak dengan orangtua. Hal ini kerena, menurut Rahman (2005: 10), sesungguhnya sikap adil dapat mencegah kedengkian dan kebencian serta dapat mewariskan kecintaan dan kerukunan di antara saudara dan membantu mereka untuk berbakti kepada kedua orangtua dan mendoakan keduanya.

Kerukunan menjadi sangat krusial di lingkungan keluarga, karena dari sinilah 
awal kenyamanan dan kedamaian selanjutnya di masayarakat dan negara. Perilaku adil orangtua dalam interaksi dengan anak-anaknya akan memberikan kontribusi bagi terciptanya kedamaian antara anak dengan anak dan juga antara anak dengan orangtua. Suasana rukun dan damai dalam keluarga menurut Baharun, Ulum, \& Azhari (2018) membuat anak saling mencintai dan menyayangi, saling mengerti dan membantu, saling menghormati dan menghargai, yang pada akhirnya akan mendapatkan keberkahan dari Allah SWT.

Oleh karena itu, sebagaimana yang telah dikemukakan sebelumnya, bahwa orangtua hendaknya selalu mengoreksi kembali apakah dirinya telah berbuat adil kepada anak-anaknya, atau malah berat sebelah kepada salah satu anak dan mengabaikan yang lainnya. Bahkan orangtua harus sangat hati-hati agar tidak pilih kasih walaupun dia tidak menyengaja, karena mau tidak mau dia harus menanggung akibat dari semua perilakunya terhadap anaknya. Sikap tidak adil dan pilih kasih orangtua kepada anak-anaknya memiliki dampak yang sangat buruk dan akibatnya akan dirasakan oleh orangtua itu sendiri, bahkan akan membahayakan salah satu anak mereka yang dikasihi lebih dari yang lainnya. Berkaitan dalam konteks ini, alNablisi (2003: 217), menyatakan bahwa pilih kasih orangtua terhadap anaknya akan menimbulkan permusuhan, kedengkian, dan kebencian di antara sesama anak-anak itu sendiri, kemudian akibat selanjutnya akan terjadilah pemutusan hubungan keluarga disebabkan oleh sikap pilih kasih orangtua mereka.

\section{PENUTUP}

Berdasarkan uraian di atas dapat diambil kesimpulan; Pertama, hadits tentang "berlaku adillah terhadap anakanakmu," yang diriwayatkan oleh Abu Dawud, al-Bukhari, Muslim, al-Nasa'iy dan
Ahmad ini dinilai sebagai hadits yang berkualitas shahih. Hal ini sejalan dengan hasil penelitian Syaikh Muhammad Nashiruddin al-Baniy terhadap hadits itu menyatakan: قال الثيخ الألباني : صديح (Syaikh al-Baniy berkata, hadits ini berkualitas shahih).

Kedua, terdapat empat nilai-nilai pendidikan yang terkandung dalam hadits di atas yaitu; Pertama, pendidikan kesetaraan. Berlaku adil kepada anak dapat memberikan nilai pendidikan kesetaraan. Dengan menerapkan sikap berlaku adil orangtua dalam bersosialisasi di lingkungan keluarga, membuat anak merasa dihargai dan memandang bahwa orangtua memperhatikan mereka secara maksimal. Mereka merasa akan diperlakukan sama akibat perilaku adil orangtua dalam kehidupan sehari-hari. Orangtua memperlakukan anak setara dengan lainnya dalam segala aspek kehidupan di keluarga. Orangtua tidak membeda-bedakan pemberian-seperti yang terkandung dalam hadits di atasantara laki-laki dan perempuan.

Kedua, pendidikan kasih sayang. Berlaku adil pada anak-seperti hadits di atas-dapat memberikan rasa kasih sayang pada diri orangtua terhadap anak. Hal ini dapat dilihat dari pengembangan perilaku adil orangtua yang memperlakukan anak sama dalam keluarga. Orangtua tidak memihak, tidak berat sebelah, dan tidak membedabedakan anak dalam segala aspek kehidupan, dapat mendorong munculnya kasih sayang di antara anak dan orangtua, karena mereka merasa diperhatikan dan diperlakukan dengan baik.

Ketiga, pendidikan demokrasi. Sebagai konsekuensi dari sikap adil, orangtua tidak pilih kasih dan memperhatikan hak-hak anak akan memupuk sikap demokratis dalam keluarga. Karena dalam perilaku adil itu, terkandung nilai demokrasi yang menjadi dasar bagi sikap dan perbuatan anak. Hubungan orangtua dengan anak dalam 
suasana keadilan akan berkembang karena menghargai hak-hak anak secara universal. Di sinilah nilai-nilai pendidikan demokratis itu tergambar, di mana seluruh anggota keluarga menghargai hak-hak anggotanya sebagai akibat dari perilaku orangtua yang selalu mengedapankan nilai-nilai keadilan dalam bergaul di keluarga.

Keempat, pendidikan kerukunan. Perilaku orangtua berbuat adil kepada anak dalam pergaulan sehari-hari di lingkungan keluarga dapat menciptakan kerukunan bagi anggota keluarga. Sikap adil dapat mencegah kedengkian dan kebencian serta dapat mewariskan kecintaan dan kerukunan di antara anak dan membantu mereka untuk berbakti kepada kedua orangtua dan mendoakan keduanya. Perilaku adil orangtua dalam interaksi dengan anak-anaknya akan memberikan kontribusi bagi terciptanya kedamaian antara anak dengan anak dan juga antara anak dengan orangtua. Suasana rukun dan damai dalam keluarga membuat anak saling mencintai dan menyayangi, saling mengerti dan membantu, saling menghormati dan menghargai, yang pada akhirnya akan mendapatkan keberkahan dari Allah SWT.

Nilai-nilai pendidikan yang terkandung dalam hadits ini sangat urgen diterapkan orangtua dalam proses pergaulan dalam keluarga. Apalagi di era milenial dengan perkembangan media sosial haruslah orangtua lebih banyak berinteraksi dengan anak dengan menerapkan nilai-nilai pergaulan yang Islami. Bagi peneliti lain diharapkan dapat melanjutkan penelitian untuk mengeksplore implementasi nilai-nilai pendidikan tentang etika berlaku adil dalam pergaulan orangtua dengan anak dalam keluarga. Sehingga dapat ditemukan seberapa besar masyarakat Indonesia menerapkan model pendidikan ini dalam kehidupan keluarga. Wallahu a'lam bi al-syawab.[]

\section{DAFTAR RUJUKAN}

Abu Dawud, Sulaiman ibn al-Asy'asy ibn Ishaq ibn Basyir ibn Syadad ibn 'Amr ibn Imran al-Azadiy al-Sijastani. Sunan Abi Dawud, Juz II, Semarang: Maktabah wa Mathba'ah Toha Putra, 2003.

Ahmad, M. Yusuf, and Syahraini Tambak. "Hubungan Metode Tanya Jawab dengan Minat Belajar Peserta Didik pada Mata Pelajaran Pendidikan Agama Islam." Jurnal Pendidikan Agama Islam Al-Thariqah, 2.1 (2017): 89-110.

Ahyar, Muzayyin. "Islamic Clicktivism: Internet, Democracy and Contemporary Islamist Activism in Surakarta." Studia Islamika, 24.3 (2017): 435-468.

Al-A'zhami, Muhammad Musthafa. Hadits Nabi dan Sejarah Kodifikasinya, terj. Oleh Meth Kiereha, Jakarta: Lintera, 1995

Al-Afriqi, Muhammad ibn Mukrim ibn Manzhur. Lisan al-'Arab, Juz. III, Beirut: Dar al-Sadir, tt.

Al-Ahdali, Muhammad Maqbuli. Mushthalah al-Hadits wa Rijaluhu, Beirut: Muassat al-Rayyan, 1990.

Al-Andalusi, Abu al-Walid Sulaiman ibn Khalaf al-Baji. al-Muntaqa Syarh alMuwatta', Juz, V, Beirut: Dar al-Fikr, tt.

Al-Askari, Abu Hilal. Mu'jam al-Furuq alLugawiyah, Damaskus: Muassasah al-Nasyr al-Islamiy, 2000.

Al-Baihaqi, Abu Bakr Ahmad ibn al-Husain ibn 'Ali ibn Musa. Sunan al-Baihaqi al-Kubra, Juz VI, Makkah alMukarramah: Maktabah Dar al-Baz, 1414 H./1994 M.

Al-Baniy, Syaikh Muhammad Nashiruddin. Shahih wa Dha'if Sunan Abi Dawud, Juz II, Kairo: Maktabah Dar al-Salam, 2007.

Al-Jurjani, Ali ibn Muhammad ibn 'Ali. alTa'rifat, Beirut: Dar al-Kitab al'Arabi, 1405 H. 
Al-Khatib, Muhammad Ajjaj. Ushul alHaditst 'Ulumah wa Mushthalahuh, Beirut: Dar al-Fikr, 1989.

Al-Manawi, Muhammad 'Abd al-Rauf. alTauqif 'ala Muhimmat al-Ta'arif, Beirut: Dar al-Fikr, $1410 \mathrm{H}$.

Al-Mizziy, Jamal al-Din Abu Yusuf. Tahzib al-Kamal Fiy Asma' al-Rijal, Beirut: Dar al-Fikr, tt., Juz XXVIII.

Al-Mubarakfuri, Abu al-'Ala Muhammad 'Abd al-Rahman ibn 'Abd al-Rahim. Tuhfah al-Ahwadzi Syarh al-Jami' alTurmudzi, Juz IV, Beirut: Dar alKutub al-'Ilmiah, tt.

Al-Munawwar, Said Agil Husin; Tambak, Syahraini; \& Kalsum, Ummi. Aktualisasi Nilai-Nilai Qur'ani dalam Sistem Pendidikan Islam, Jakarta: Ciputat Press, 2003.

Al-Nablisi, Syaikh Abd al-Ghani. Tahqiqul Qadhiyah fiy al-Farqi Baina alRisywah wa al-Hadiyah, Kairo: Maktabah al-Zahra', 2002.

al-Nawawi, Imam. Raudhah al-Thalibin wa Umdat al-Salikin, Juz I, Beirut: Dar alKutub al-'Ilmiah, 1421 H./2000 M.

Al-Raziy, Fakhr. al-Jarh wa al-Ta'dil, Juz III, Beirut: Libanon, $\mathrm{tt}$.

Al-Sabiq, Sayyid. Fiqh al-Sunnah, Juz III, Beirut: Dar al-Kitab al-Arabi, tt.

Al-Tirmizi, Muhammad Mahfuzh bin Abdullah. Manhaj Dzawiy al-Nazhar, terj. Ahmad bin Sa`ad bin Nabhan, Surabaya: Pustaka Nasional, 1994.

Al-Zuhailiy, Wahbah. al-Fiqh al-Islami wa Adillatuh, Juz V, Suriah: Dar al-Fikr al-Mu'ashiir, 1418 H./1997 M.

Amril, M. Etika dan Pendidikan, Yogyakarta: Aditya Media dan LSFK2P Pekanbaru, 2005.

Azra, Azyumardi, et. al. Ensiklopedi Islam Jilid 4, Nina M. Armando, et. al., (ed.), Jakarta: Ichtiar Baru van Hoeve, 2005.

Azra, Azyumardi, et. al.. Ensiklopedi Islam Jilid I, Nina Armando, et. al., Jakarta: Ichtiar Baru van Hoeve, 2005.

Baharun, Hasan, Mohammad Bahrul Ulum, and Ainun Najib Azhari. "Nilai-nilai
Pendidikan Islam dalam Tradisi Ngejot: Konsep Edukasi dalam Membangun Keharmonisan dan Kerukunan Antarumat Beragama Berbasis Kearifan Lokal." Fenomena: Jurnal Penelitian, 10.1 (2018): 1-26.

Harmakaputra, Hans Abdiel. "Islamism and Post-Islamism:"Non-Muslim" in Socio-Political Discourse of Pakistan, the United States, and Indonesia." AlJami'ah: Journal of Islamic Studies, 53.1 (2015): 179-204.

Hasan, M. Ali. Pedoman Hidup Berumah Tangga Dalam Islam, Jakarta: Penerbit Siraja, 2003.

Hatmanto, Soenarto. Pendidikan Kesejahteraan Keluarga, Surabaya: Bina Ilmu, 1986.

Ibn Zakariya, Abu al-Husain Ahmad ibn Faris. Maqayis al-Luhgah, Juz III, Beirut: Ittihad al-Kitab al-'Arab, 1423 H./2002 M.

Ibnu Hajar al-Asqalaniy, Syihab al-Din Ahmad ibn Ali. al-Ishabah fiy Tamyiz al-Shahabah, Juz VI, Beirut: Dar alKutub al-Ilmiyah, tt.

Ibnu Hajar al-Asqalaniy, Syihab al-Din Ahmad ibn Ali. Tahzib al-Tahzib, Juz $X$, Beirut: Dar al-Fikr, 2008.

Ibnu Hamzah al-Husaini al-Hanafi alDimasyqi. al-Bayan wa al-Ta'rif fiy Asbab Wurud al-Hadits al-Syarif, (Asbabul Wurud Latar Belakang Historis Timbulnya Hadits-hadits Rasul), terj. M. Suwarta Wijaya dan Zafrullah Salim, Juz. I, Jakarta: Kalam Mulia, 2006.

Imam Ahmad, Abu Abdullah Ahmad bin Muhammad bin Hanbal. Musnad Imam Ahmad Ibn Hanbal, Jilid II, Beirut: Dar al-Fikr, tt.

Imam al-Bukhari, Abu Abdillah Ahmad bin Muhammad bin Isma'il al-Bukhari. Shahih al-Bukhari, Juz IX, Semarang: Maktabah wa Mathba'ah Toha Putra, 2003.

Imam al-Nasa'iy, Ahmad bin Syu'aib bin 'Ali bin Bahr bin Dinar Abu Abd alRahman. Sunan al-Nasa'iy, Juz IV, 
Semarang: Maktabah wa Mathba'ah Toha Putra, 2003.

Imam Muslim, Abu al-Husain Muslim bin al-Hajjaj bin Muslim al-Qusyairi alNaisaburiy. al-Jami' al-Shahih (Shahih Muslim), Juz V, Semarang: Maktabah wa Mathba'ah Toha Putra, 2003.

Irawan, Bambang. "Tafsir Ayat-ayat Kasih Sayang dalam Masyarakat Plural." Jurnal Theologia, 23.1 (2017): 75-88.

Lubis, Dahlia. "Persepsi Mubaligh dan Mubalighah terhadap Kesetaraan dan Keadilan Gender di Kota Medan." MIQOT: Jurnal Ilmu-ilmu Keislaman, 40.1 (2016). 1-24.

Muhmidayeli. Filsafat Pendidikan Islam, Sabda Ali Mifka (ed.), Bandung: Refika Aditama, 2011.

Mukodi. Bilik-Bilik Demokrasi dalam Pendidikan, Shahih: Journal of Islamicate Multidiciplinary, 2.2 (2016). 113-123.

Musmualim, Musmualim, and Muhammad Miftah. "Pendidikan Islam Di Keluarga Dalam Perspektif Demokrasi (Studi Pemikiran Hasan Langgulung dan Abdurrahman an Nahlawi)." Jurnal Penelitian, 10.2 (2016). 345-398.

Musthafa, Ibrahim, et. Al. al-Mu'jam alWasith, Juz I, Kairo: Maktabah Dar alSalam, 2007.

Octavia, Lanny. Islamism And Democracy: A Gender Analysis on PKS's Application of Democratic Principles and Values, al-Jami'ah: Journal of Islamic Studies, 50.1 (2012). 1-22.

Qaimi, Ali. Menggapai Langit Masa Depan Anak, Muhammad Jawad Bafaqih (terj.), Bogor: Cahaya, 2002.

Rahman, Mufiqur. Demokrasi dalam Filsafat Pendidikan Barat dan Islam (Kajian tentang Nilai-Nilai Demokrasi dan Implementasinya dalam Konteks Pendidikan Indonesia), Cendekia: Jurnal Studi Keislaman, 3.2 (2018). 138-151.
Rahmatullah, Azam Syukur. Konsepsi Pendidikan Kasih Sayang dan Kontribusinya terhadap Bangunan Psikologi Pendidikan Islam, Literasi: Jurnal Ilmu Pendidikan, 5.1 (2017). 29-52.

Saputra, Rangga Eka. Islam, Demokrasi, dan Instutisi Politik Indonesia, Turki, dan Dunia Islam, Studia Islamika: Indonesian Journal for Islamic Studies, 4.1 (2017). 185-204.

Shidiq, Ngarifin. Transformasi Pendidikan Demokrasi, al-Qalam: Jurnal Kependidikan, 8.2 (2015). 32-48.

Sulaiman, M.I. Pendidikan dalam Keluarga, Bandung: Mizan, 1994.

Syarifuddin, Ahmad. Mendidik Anak Membaca, Menulis, dan Mencintai alQur'an, Jakarta: Gema Insani Press, 2004.

Tambak, Syahraini. Membangun Bangsa Melalui Pendidikan: GAgasan dan Pemikiran dalam Mewujudkan Pendidikan Berkualitas untuk Kemajuan Bangsa, Yogyakarta: Graha Ilmu, 2013.

Tambak, Syahraini. Pendidikan Komunikasi Islami: Pemberdayaan Keluarga Membentuk Kepribadian Anak, Jakarta: Kalam Mulia, 2013

Tambak, Syahraini; Amril M; Khairi, Zuriatul; Sukenti, Desi. Development of Madrasah Teacher Professionalsm by Strengthening the Khalifah Concept and Islamic Psychosocial Perspektif. Proceeding of the International Conference on Islamic Education (ICIE 2018), Advance in Social Science, Education and Humanities Research, Atlantis Press, 2018.

Tim Penyusun. Kamus Besar Bahasa Indonesia, Jakarta: Balai Pustaka, 1988.

Ubaedillah, A. \& Abdul Rozak, (peny.). Pendidikan Kewarganegaraan (Civic Educatioan); demokrasi, Hak Asasi Manusia, dan Masyarakat MAdani, 
Jakarta: Kencana Prenada Media, 2008.

Wensinck, AJ. Mu'jam al-Mufakhrasy li Alfazh al-Hadits al-Nabawiy, Jilid II, Mohd. Fu'ad Abd. al-Baqi' (ed.), Kairo: Maktabah Dar al-Salam, 2008. Yahya Athif, Muhammad bin. Huququl Abna' 'alal $A b a$ ', Riyadh: Dar alQasim, 2004. 